\title{
Comparison of mental health, resiliency in spouses and marital satisfaction of men with psychotic disorders with healthy spouses
}

\author{
Somayeh Shokrgozar ${ }^{1}$, Mahnaz Fallahi Kheshti Masjedi ${ }^{2}$, Bahman Akbari ${ }^{3}$, Afsar Montakhabi ${ }^{4}$ \\ 1-Assistant Professor, Department of Psychiatry, Cognitive Behavioral Sciences and addiction, Kavosh research \\ center, Shafa Hospital, Faculty of Medicine, Guilan University of Medical Sciences, Rasht, Iran. ORCID: 0000- \\ 0002-2994-051X \\ 2-Guilan University of Medical Sciences, Guilan,Rasht, St. Azadegan Health Department Iran. ORCID: 0000- \\ 0002-5180-0644Ｅ-mail: mahnaz.fallahi@gmail.com \\ 3-Associate Professor of Psychology, Faculty of Literature and Humanities, Islamic Azad University, Rasht, \\ Iran. ORCID: 0000-0003-2053-044X \\ 4-Master of Science in Clinical Psychology, Psychology Specialist, Healing Education Center, Rasht, Iran. \\ ORCID: 0000-0003-0603-2524
}

\section{Abstract}

Received: 11/07/2018

Accepted: 30/11/2018

Introduction: The burden of taking care of patients with psychotic disorders can increase stress and reduce mental health, quality of life and marital satisfaction.

Aim: The purpose of this study was to compare mental health, resilience and marital satisfaction in women with schizophrenia and mood disorder with spouses.

Method: The research method was descriptive-analytic and the statistical population consisted of the spouses of all male patients admitted in Rasht psychiatric hospital in Rasht, Iran during the period from 1394 to 1395 . They were diagnosed with psychotic disorders. 187 women were selected using purposeful sampling and 187 normal-wife women were selected and completed three questionnaires including mental health check list, Enrique's Conner, Davidson and marital satisfaction questionnaires. SPSS-22 software and multivariate analysis of covariance analysis were used to analyze the data.

Results: The research showed that there was a significant difference between two groups in terms of mental health $(\mathrm{t}=4.387)$. Women with psychosis spouses had more symptoms than those with healthy husbands under the mental health components. The survival rate of women with menopausal psychosis was lower than normal group $(\mathrm{t}=3.231)(\mathrm{P}=0.001)$. The components of marital satisfaction were significant at the level of 0.05 . This indicates a low level of marital satisfaction among the women compared to the peer group.

Conclusion: Responsibility for living among women with schizophrenic wife has been more than bipolar disorder due to a severe decline in these patients' performance. These psychological stresses have led to a decrease in quality of life, persistence and dissatisfaction with marital life, which led to a decrease in mental health they will be.

Keywords: Mental health, marital satisfaction, resiliency, spouses with psychotic disorders

\footnotetext{
How to cite this article : Shokrgozar S, Fallahi Kheshti Masjedi M, Akbari B, Montakhabi A. Comparison of mental health, resiliency in spouses and marital satisfaction of men with psychotic disorders with healthy spouses. Shenakht Journal of Psychology and Psychiatry.
} 2018; 5 (5): 30-42 .URL :http://shenakht.muk.ac.ir/article-1-499-fa.pdf

Copyright $@ 2018$ the Author (s). Published by Kurdistan University of Medical Sciences. This is an open access article distributed under the terms of the Creative Commons Attribution-Non Commercial License 4.0 (CCBY-NC), where it is permissible to download, share, remix, transform, and buildup the work provided it is properly cited. The work cannot be used commercially without permission from the journal. 


\section{مقايسه سلامت روانى، تاب آورى و رضايت زناشويى در زنان داراى همسران مبتلا به اختلالات روانبريشى با زنان دار واى همسران سالم}

سميه شكر كزار '، مهناز فلاحى '، بهمن اكبرى"، افسر منتخبى ا. استاديار گروه روانيزشكى، مركز تحقيقات علوم رفتارى - شناختى و اعتياد إكاوش"، بيمارستان شفا، دانشكده يزشكى، دانشكاه علوم يزشكى گيلان، رشت، ايران. ז. دكتراى روانشناسى تربيتى، دانشكاه علوم بزشكى كيلان، واحد سلامت روان، معاونت بهداشتى دانشكاه علوم يزشكى گيلان، واحد بهداشت

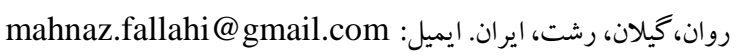

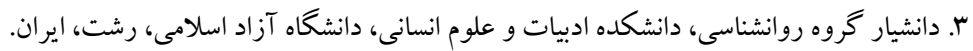

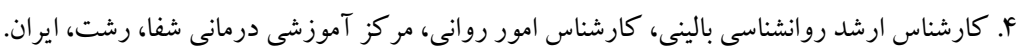

مقدمه: بار مسئوليت مراقبت از بيماران روانيريش مىتواند باعث افزايش استرس و كاهش سلامت روان، كيفيت زندكى و رضايت زناشويى در آنها گردد. هدف: يروهش حاضر با هدف مقايسه سلامت روانى، تابآورى و رضايت زناشويى در زنان داراى همسر مبتلا به اختلالات

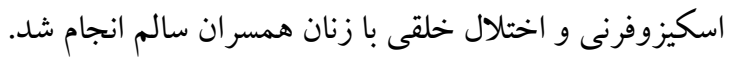

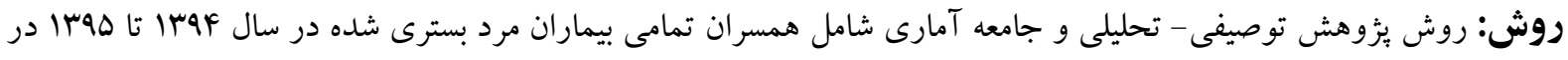

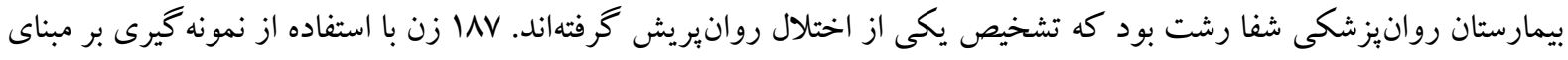

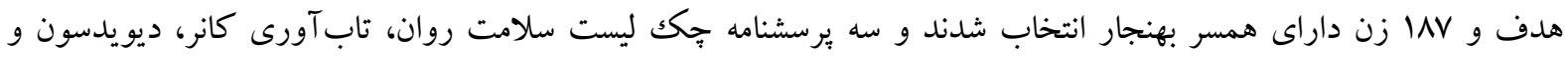

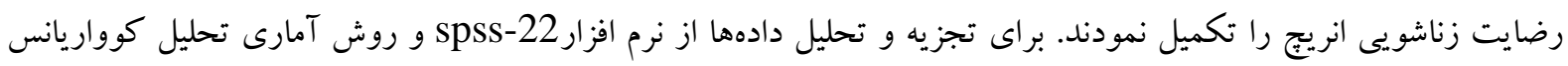
جندمتغيرى استفاده شد.

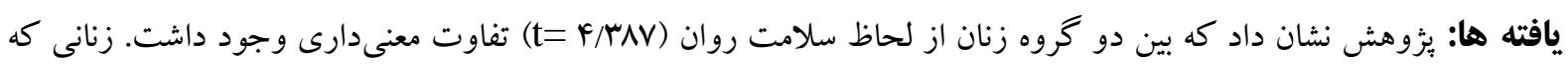

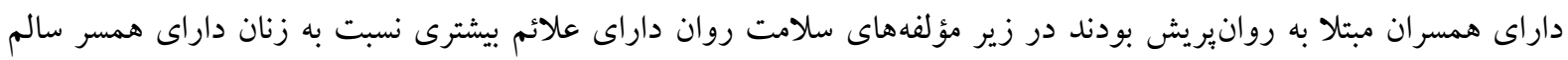

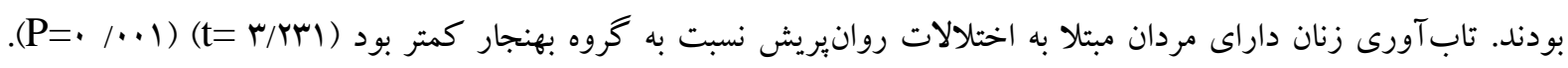

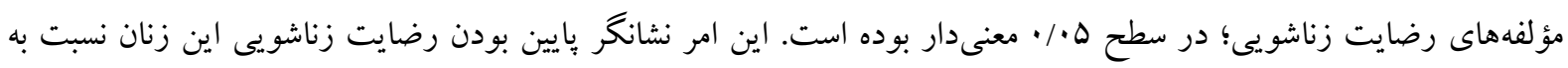
كروه همتا بود. نتيجه كيرى: مسئوليت زندگى در بين زنان داراى همسر مبتلا به اسكيزوفرنى به دليل افت شديد عملكرد اين بيماران بيشتر از

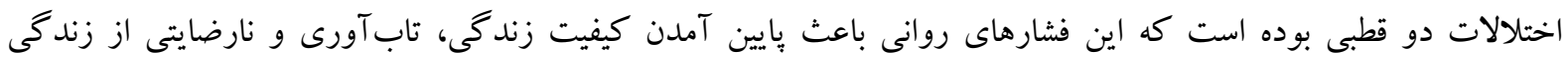

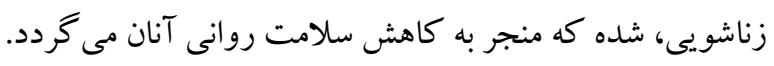

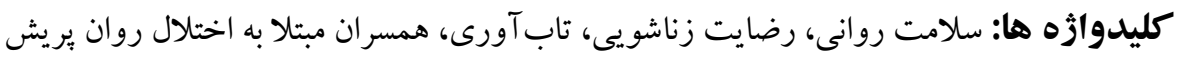




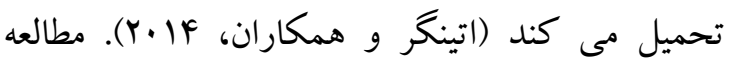
انجام شده توسط انجمن ملى مراقبت از خانواده اختلالات روانيزشكى مزمن باعث ايجاد مشكلات نشان داد كه خانواده هاى بيماران مبتلا به (199V) روانى و اجتماعى زيادى براى بيماران و مراقبين اختلالات روانى مزمن، خود استرس زيادى را تجربه مى كنند كه اين مسئله در نهايت منجر به مشكلات سلامت روان جدى در اين خانو اده ها مى شود (عمران

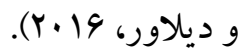
مراقبين در برآورده كردن نيازهاى بيماران داراى توانمندى هاى متفاوت و محدودى هستند كه اين حالت، فرد مراقبت كننده را در مواجهه با تغييرات و

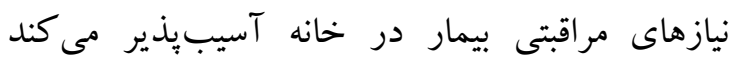
(كاكه يوريزار و مالدونادو، 9. +r). در جنين شرايطى

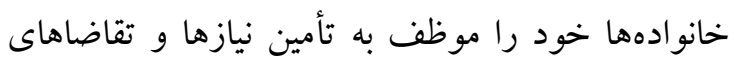
بيمار خود دانسته و مجبور به تحمل همه ناملايمات و

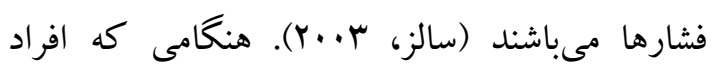
مراقبت كننده نيازهاى مراقبتى بيمار را بيشتر از توانايى و منابع حمايتى خود ارزيابى كنند، آنها نه تنها اين موقعيت ايجاد شده را استرسزا تلقى مى كنند، بلكه اين حالت مىتواند سلامت عمومى و روانى آنها را نيز به خطر اندازد (فولدمو و همكاران، هـ.r). مراقبت از بيمار مبتلا به روان بريش، مسئوليتى جند

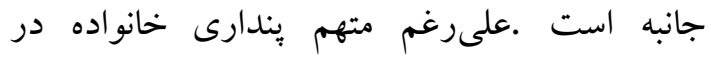

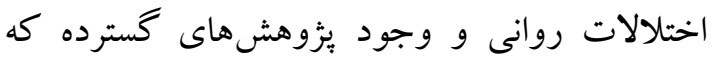
نشان مىدهد مشكل بهداشت روانى در يكك عضو خانواده، مىتواند تهديدى براى كل نظام خانواده به شمار آيد و اين كه سطوح بالاى هيجان ابراز شده در خانو اده با مشكلات ارتباطى مرتبط است و ميزان عود

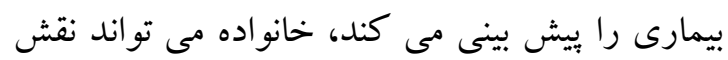

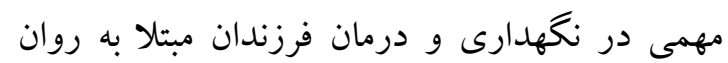
بريشى داشته باشد (يريور و همكاران، 19 (Y). سريرستى و نخهدارى از يكك بيمار روانى، همانند اسكيزوفرنيا، سبب فشار روانى مانند بىنظمى در وعده ئري مىشود. اين مشكلات روانى اجتماعى به طور كل به

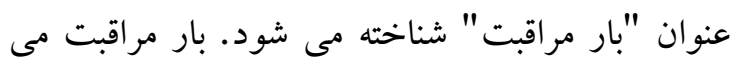
تواند بر سلامت عمومى و سلامت روان مراقبت كننده

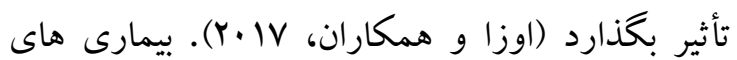
روانى، به خصوص اسكيزوفرنى، مى تواند اثرات مضر

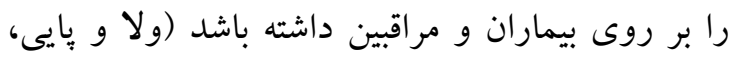
rا.ץ). در حقيقت مراقبين بيماران مبتلا به اختلالات روانى مزمن بارهاى قابل توجهى از جمله مشكلات

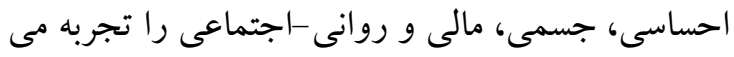

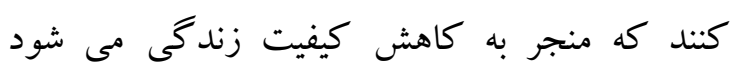
( سلطانى نزاد و همكاران، IV) (Y).

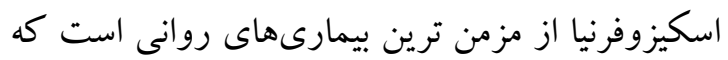

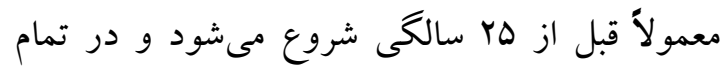

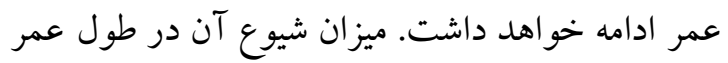

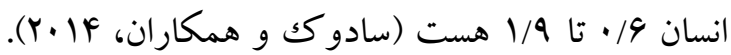
كزارش سازمان بهداشت جهانى نشان مىدهد كه حدود الها ميليون نفر مبتلا به افسردگى و צب ميليون

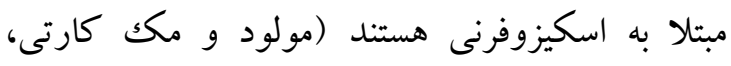

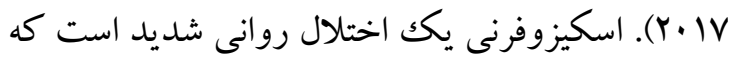
بار مسئوليتى را براى مراقبين ايجاد مى كند. خانواده ها به علت رفتار غيرطبيعى بيمار و اختلال عملكرد اجتماعى و شغلى، بسيارى از ناراحتى هاى جسمى، احساسى و مالى را تجربه مى كنند (كيت و همكاران، .$(Y \cdot \mid r$ اين بيمارى به دليل ايجاد اختلال در عملكرد شغلى و

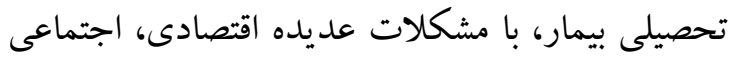
و فردى همراه بوده و هزينه هاى درمانى و غيردرمانى زيادى را همجون از دست دادن نيروى كار-به دليل بيمارى يا مراقبت بستخان- بر بيمار، خانواده و جامعه 
كنند (اونگار و همكاران، در مورد تجربه مراقبت از بيماران مبتلا به اسكيزوفرنى در كشورهاى مختلف مانند شيلى (كوموندسون،

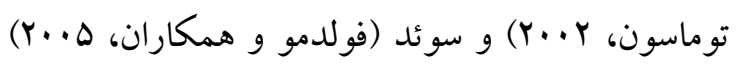

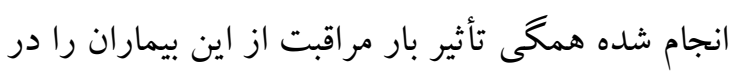
سلامت روانى خانواده به روشنى نشان داده و اذعان داشتند كه خانوادههايى كه بهطور مستقيم با اين بيماران سر و كار دارند از كسالت عصبى خفيفى رنج مىبرند؛ و برخى از آنها حتى ممكن است به علت بايين آمدن

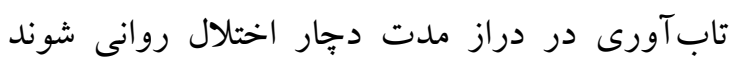

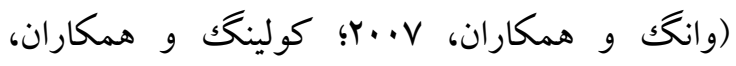

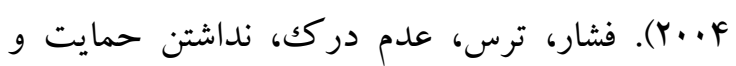
ترديد مداوم بعضى از مواردى است كه خانوادههاى

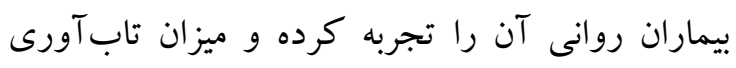

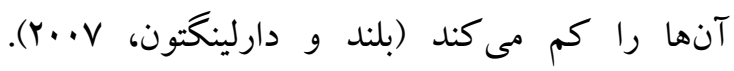

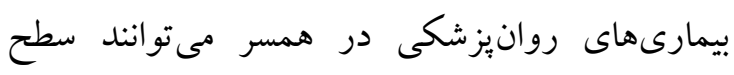

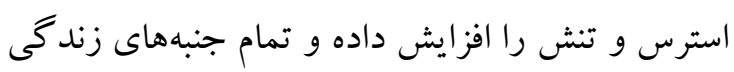

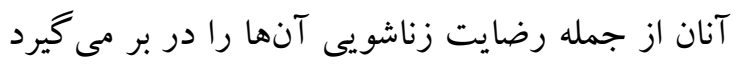

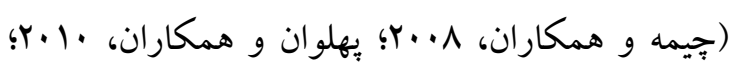

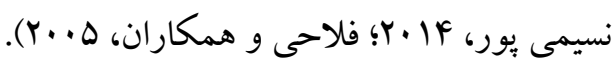

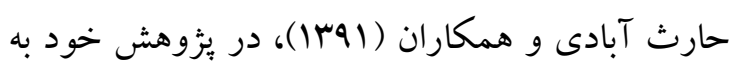
اين نتيجه رسيدند كه \&/1/ه درصد از مراقبان اصلى بيماران مبتلا به اختلال روانى مزمن از فشار روانى شديد رنج مى برند و اين فشار روانى در زنان بيشتر از مردان

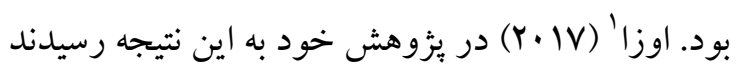

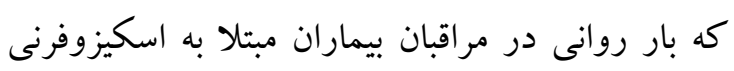
بيشتر از ساير اختلالات مزمن بوده است. خود كشى نيز

$$
\text { در اين مراقبان بيشتر بود. }
$$

از آنجائى كه زنان و دختران عمواً به به بود عنوان مراقبين اوليه بيماران در منزل عمل مى كنند مسئوليت مداوم

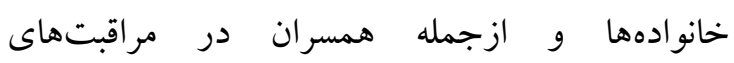

هاى غذا و ساعت خواب، به تأخير افتادن مراقبتهاى

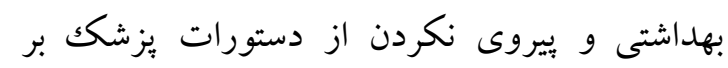

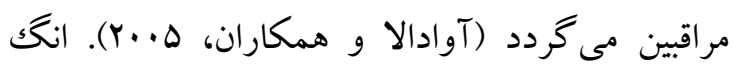

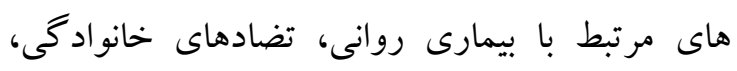

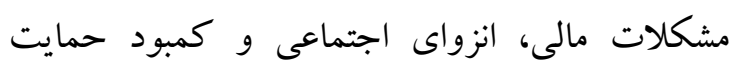

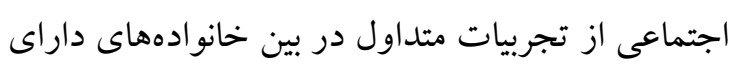
اين نوع از بيماران است (تكينسكى، .... (Y). همسران بيماران مبتلا به اختلالات روانى مزمن نظير اسكيزوفرنى ليماري از نظر سلامت روانى بسيار تحت تأثير قرار مى گيرند.

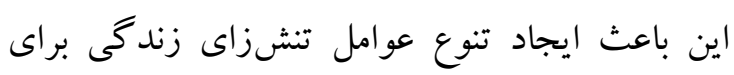

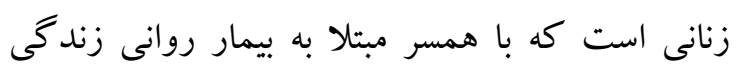

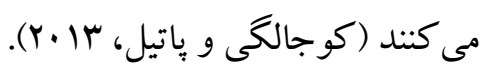

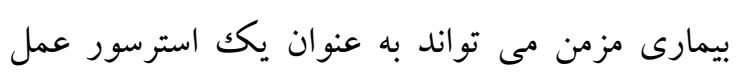

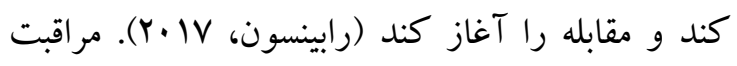
دائمى از بيماران مبتلا به بيمارى مزمن، از جمله بيمارى

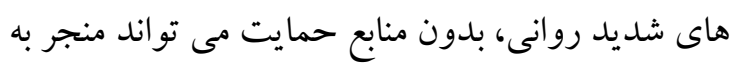

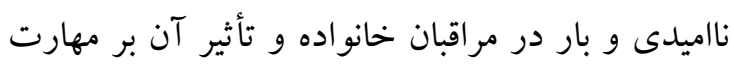

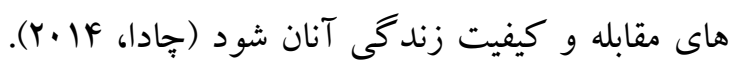
زنانى كه با همسران بيمار روانى خود در يكك خانه زندكى مى كنند ممكن است تجربههاى مختلفى را در زندكى خود از نخرانى، ترس، ناكامى، خشم، احساس

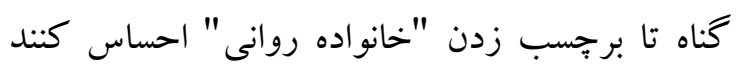

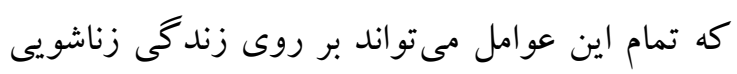
آنها اثر گذاشته و منجر به نارضايتى زناشويى از

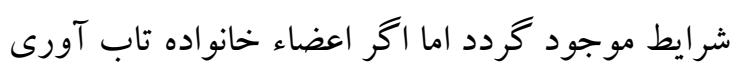
بيشترى داشته باشند مى تواند بر استرسهاى مرتبط با

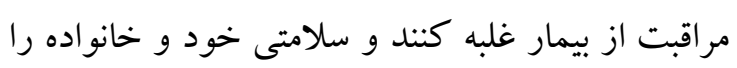

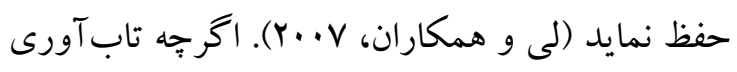

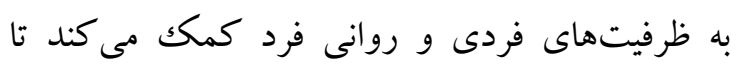

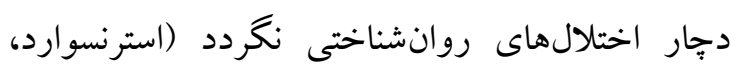

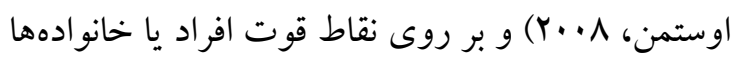
تمركز دارد كه آنها را قادر مى كند بر سختى روى غل غلبه 
بيمارى اعصاب و روان نداشته، انتخاب شدند. معيار ورود به اين يُوهش عدم سابقه بيمارىهاى اعصاب و روان و عدم سابقه بيمارى جسمى شديد بوده است. معيار خروج از يثوهش زمانى انجام مىشد كه نمونهها عليرغم داشتن سواد كافى و هوش طبيعى قادر به جواب دادن همه سؤالات نبوده و يرسشنامه ناقص تكميل مىشد. براى جمع آورى دادهها علاوه بر جـك ليست

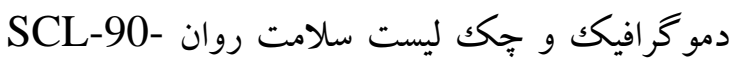
R مقياس تابآورى كانر و ديويدسون و برسشنامه رضايت زناشويى انريج استفاده گرديد.

ابزار جك ليست سلامت روان' SCL-90-R اين ابزار توسط دراكوتيس و همكاران (IAVY) طراحى شده است و شامل ·9 سؤال براى ارزشيابى علائم روانى

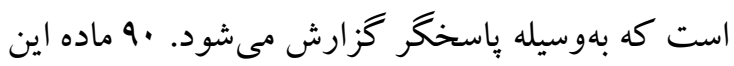
آزمون 9 بُعد مختلف شكايات جسمانى، وسواس و به اجبار، حساسيت در روابط متقابل، افسردگى، اضطر اب، لون،

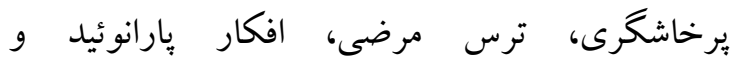

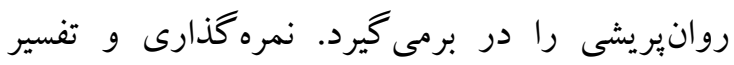
آزمون بر اساس سه شاخص ضريب شاخص كلى رونى

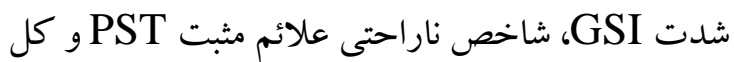

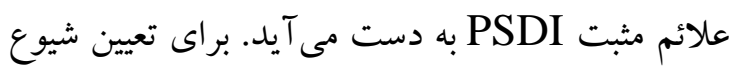
علائم روانيزشكى در هر حيطه از نقطه برش

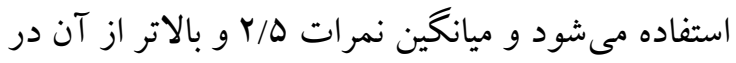
هر حيطه بهعنوان حالت مرضى به شمار مى آيد. جككليست مذكور، در مطالعه مدبرنيا و همكاران ضريب پيايانى با روش باز آزمايى (r=0.93)، دو نيمه

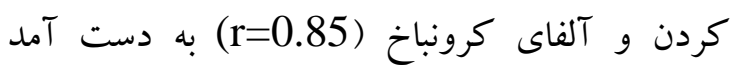

(مدبرنيا، شجاعى تهرانى، فلاحى و فقيريور، · (Y).

\footnotetext{
2- Symptom Chek List - 90- Revised
}

روانشناختى و سلامتى يكك عضو ناتوان، به كاهش قابل ملاحظه در سلامت روان و كيفيت زندگ وانى مراقبان مى انجامد (هربر و همكاران، سا •Y). با توجه به اهميت خانواده به ويزه همسران، به عنوان مهم ترين و بهترين حامى اجتماعى بيماران مزمن روانى

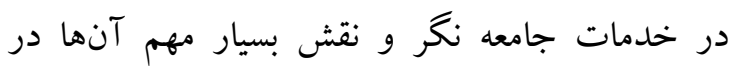

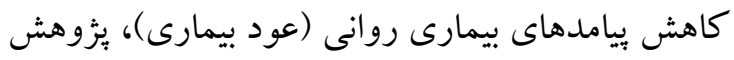
حاضر جهت بررسى سطح سلامت روان، تاب آورى و رضايت زناشويى در همسران مردان بسترى در مركز روانيزشكى به دليل اختلالات اسكيزوفرنى و اختلال خلقى طراحى شده است. نتيجه يثزوهش حاضر مى تواند زمينهساز يُزوهشهاى مربوط به اثربخشى نمايش

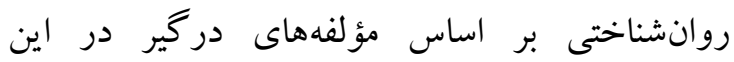
اختلالات در جهت ارتقاى سطح سلامت روان مراقبين مبتلايان به بيمارى هاى مزمن خردد.

روش ثيزوهش در اين بررسى از نوع توصيفى - تحليلى (على- مقايسهاى) است. جامعه آمارى همسران كليه

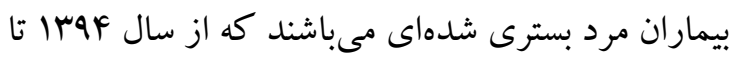
سال هوها در مركز روانيزشكى آموزشى درمانى شفا

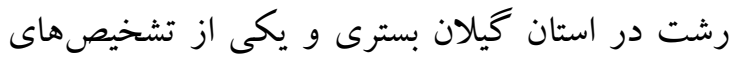
اختلالات روانيريشى (اسكيزوفرنى و اختلال دوقطبى)

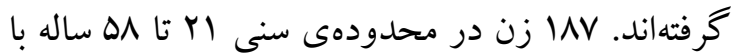
ميانگين TV/V9 و انحراف استاندارد 9/AV با استفاده از روش نمونه گيرى بر مبناى هدف كه همسران آنها در

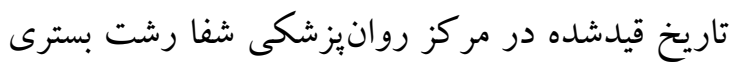
بودند كه بعد از توضيح هدف يزوهش و اخذ

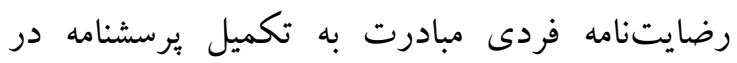
حضور روانشناس شاغل در بخش كردند و 1AV زن داراى همسر بهنجار كه اين گُروه نيز از همراهان ملاقات كنندها بودند و بنا بر اظهار خودشان سابقه 
زناشويى ب-موضوعات شخصيتى F- ا-ارتباط زناشويى ه-حل تعارض 9-نظارت مالى V- فعاليتهاى مربوط به اوقات فراغت ^- روابط جنسى ه-ازدواج و بجهها

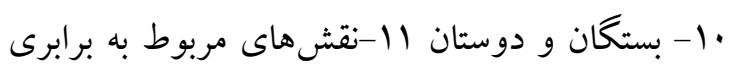

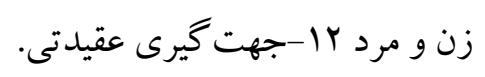

ياسخ به سؤالات به صورت ه زَينه اى (كاملاً موافق،

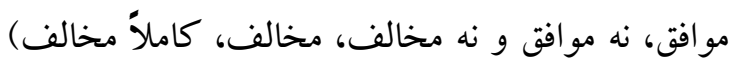

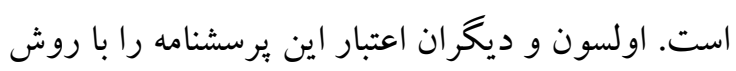

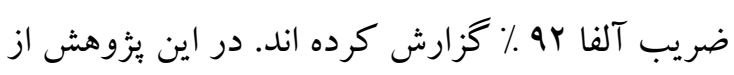
فرم FV سؤالى انريج استفاده شده كه ضريب آلفاى آن

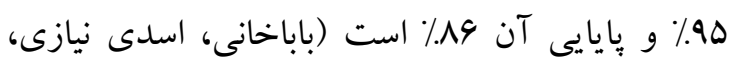

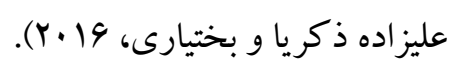

\section{يافته ها}

جدول شماره (1) ويز گمىهاى جمعيت شناختى كروههاى مطالعه را بر اساس سن نشان مى هد.

مقياس تابآورى كانو و ديويدسون (CD-RISC) :

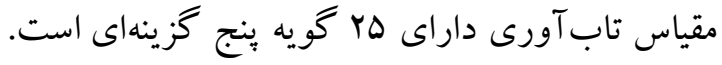
براى تعيين پيايايى مقياس تابآورى كانر و ديويدسون

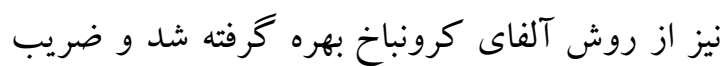
هايايى 91/· به دست آمد (كونور و ديويدسون، r..r). كه در ايران هنجاريابى شده است. داراى هr عبارت است كه بر اساس تحليل عاملى انجامشده، ينج زير مقياس شامل "صلاحيت و كفايت

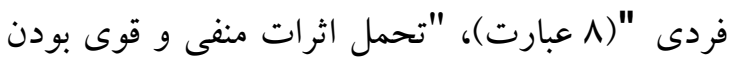

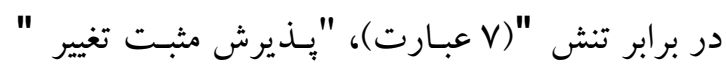

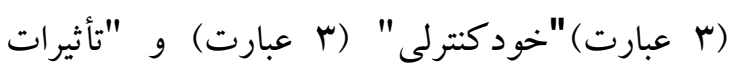

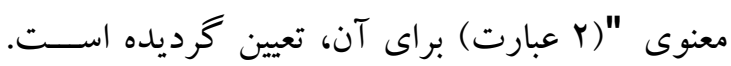
روش نمره گذارى مقياس بر اسـاس مقياس ليكرت از

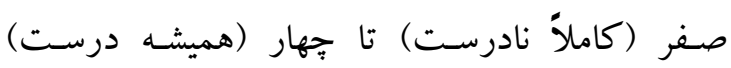
است و براى اندازهيرى تابآورى يك نمره كل محاسبه مىشود كه حداكثر نمره ..1 و حداقل نمره

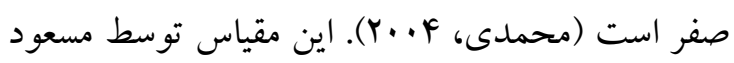
(IMAF)

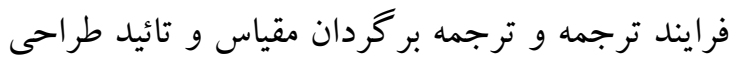

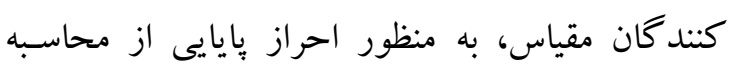
آلفاى كرونباخ و براى تعيين روايى از روش تحليل

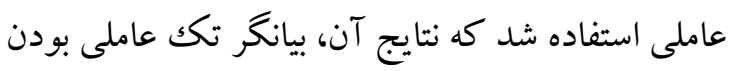
مقياس بود. آلفاى كرونباخ مقياس، سوه/

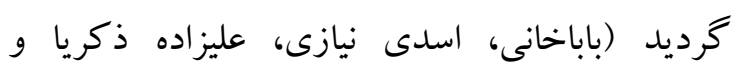

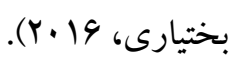

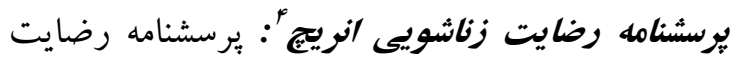

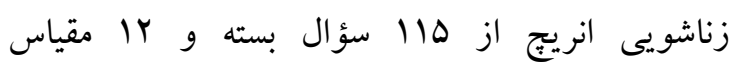
تشكيل شده است كه به جز مقياس اول آن كه ه سؤال دارد بقيه مقياسها شامل ·• سؤال تست است مقياس اين خِرسش نامه شامل:ا- بِاسخ قراردادى ب-رضايت 


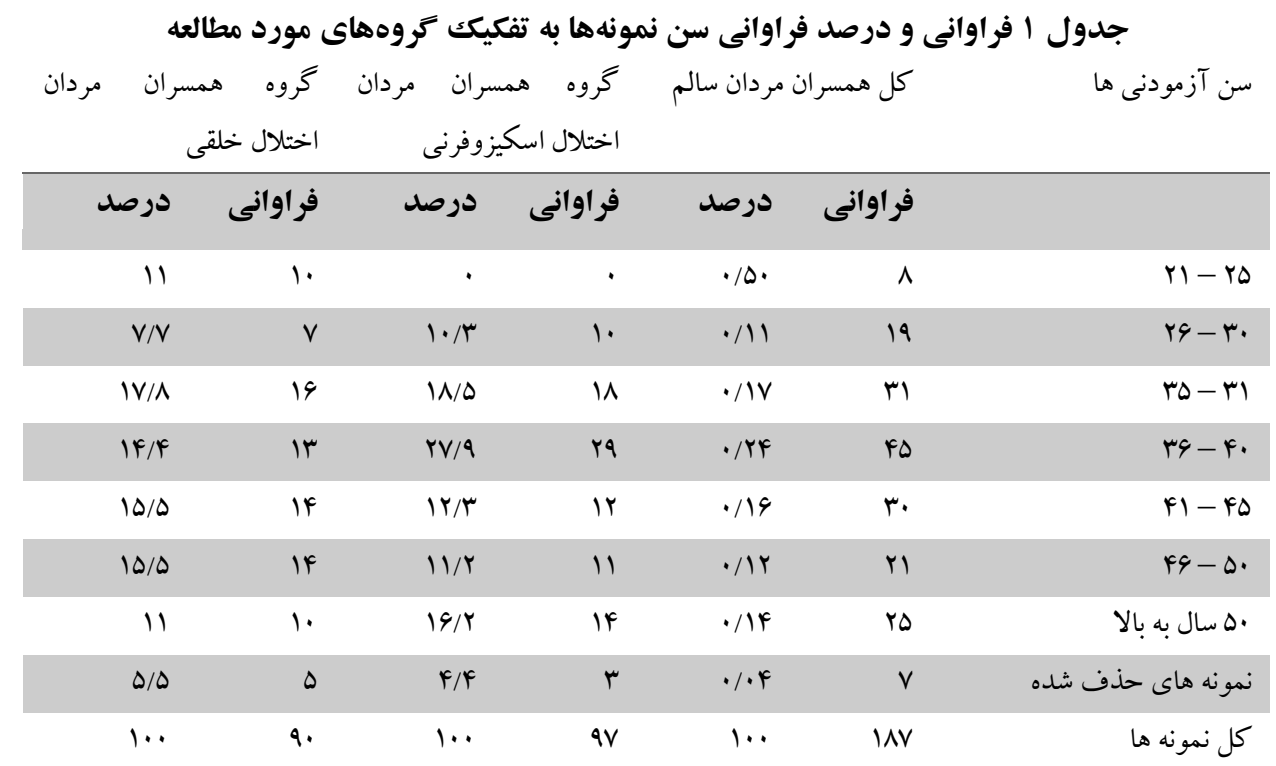

از لحاظ مؤلفههاى سلامت روان تفاوت معنىدارى وجود دارد. براى بررسى اينكه گروهها در كدام يكك از مؤلفه هاى سلامت روان با يكديخر تفاوت دارند از تحليل واريانس جند متغيره استفاده شد كه در جدول

$$
\text { (Y) نتايج آن كزارش شده است. }
$$

مقدار F تحليل كوواريانس جندمتغيرى بررسى تفاوت بين سلامت روان كروه همسر ان مردان داراى اختلالات اسكيزوفرنى و خلقى را با گروه همسران مردان سالم در مؤلفهاى سلامت روان با ميزان اثر بيالايى = NVV9

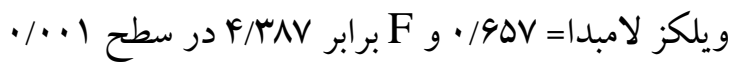
معنى دار است؛ بنابراين مىتوان كفت كه بين دو گروه

جدول ب نتايج تحليل جند متغيرى روى ميانتين سلامت روان و مؤلفه هاى آن در دو گروه همسران مردان داراى اختلالات روان يريشى با تروه شاهد موند

\begin{tabular}{|c|c|c|c|c|c|c|c|c|}
\hline آمارى & اند اند & $\mathbf{p}$ & $\mathbf{F}$ & $\begin{array}{l}\text { MS } \\
\text { خطا }\end{array}$ & $\begin{array}{l}\text { MS } \\
\text { آزمايشى }\end{array}$ & $\begin{array}{l}\text { SS } \\
\text { خطا }\end{array}$ & $\begin{array}{l}\text { TS } \\
\text { آزمايشى }\end{array}$ & مؤلفه \\
\hline 1 & $\cdot / \Lambda$ & $\cdot / \cdot \cdot 1$ & $11 / 91$ & $F Y / Q F$ & $\Delta 11 / 9$. & $9 V \cdot . / \cdot \Delta$ & IDrd/Vr & شكايت جسمانى \\
\hline$\cdot / 9 \Delta$ & $\cdot / 1$ & $\cdot / \cdot \cdot 1$ & $\Delta / \Lambda \Lambda$ & $F 1 / 9 \mathrm{~V}$ & $T F \Delta / F D$ & 190.191 & VMG/MD & وسواس - اجبار \\
\hline 1 &.$/ 19$ & $\cdot / \cdots 1$ & $I r / Y$. & $M Y / Y F$ & rar/\&D & $0 . Y 9 / 9 T$ & $11 \wedge \cdot / r V$ & حساسيت در روابط \\
\hline 1 & $\cdot / r r$ & $\cdot / \cdot+1$ & $\mid F / g r$ & $9 F / V$ & ITMG/NY & $|F V V N / A|$ & $F 19 . / 1 \mathrm{~V}$ & افسردگى \\
\hline$\cdot / 99$ &.$/ 19$ & $\cdot / \cdot 1$ & $9 / 9 V$ & $r \cdot 19$. & $r \cdot \Delta / Q q$ & HYIF/AI & $919 / 94$ & اضطراب \\
\hline$\cdot 194$ & $\cdot / \cdot v$ & .1 .9 & $r / \Delta \Lambda$ & $৭ / ৭ \diamond$ & $r \Delta / V G$ & $1 \Delta \Delta r / \Gamma$ & $W / r q$ & خصومت \\
\hline$\cdot / 99$ &.$/ 11$ & $\cdot / \cdot 1$ & $9 / \mathrm{H}$ & $N / 9 \mu$ & $\Delta \Delta / \cdot V$ & 1 1rF/99 & $190 / Y r$ & ترس مرضى \\
\hline$\cdot / 90$ & $\cdot / 1 r$ & $\cdot 1 \cdot+1$ & $9 / 19$ & D D/r/ & $\Lambda r / M r$ & $r \cdot \Delta r / F F$ & $Y F V / \cdot \cdot$ & افكار پيارانوئيدى \\
\hline.$/ 9 F$ & .1 .9 &.$/ \cdots 1$ & $\Delta / 9 F$ & $|F / \mu|$ & $\Lambda \cdot / A \vee$ & rrm/la & YFY/91 & روان يريشى \\
\hline 1 & $\cdot / r r$ & $\cdot / \cdots$ & $10 / 11$ & $1 r q \cdot / 19$ & YI. YE/AD & r199V9/IV & $\Delta r \cdot \Lambda \cdot / \Delta V$ & كل مؤلفهها \\
\hline
\end{tabular}


تجزيه و تحليل دادهها نشان داد كه بين تاب آورى همسران مردان داراى اختلالات سايكوز و گرووه بهنجار

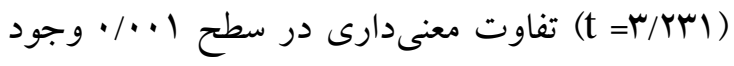
دارد و تاب آورى در زنان داراى همسران سايكوز بهور معنا دارى كمتر از زنان داراى همسران سالم است. با توجه به جدول r مقدار F تحليل كوواريانس جندمتغيرى بررسى تفاوت گروه همسران سالم با بان همسران مردان داراى اختلالات اسكيزوفرنى وگروه بعري همسران مردان داراى اختلالات خلقى در مؤلفههاى با

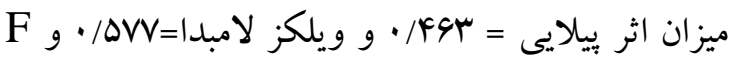

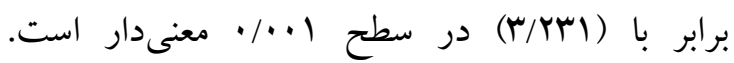

مقدار F براى مؤلفههاى شكايت جسمانى (1)/9I)، وسواس- اجبار (ه/MA)، حساسيت در روابط متقابل

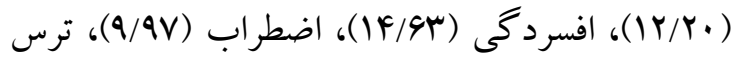

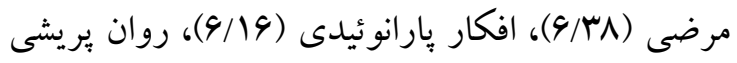

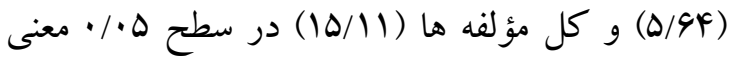
دار است و اين يافتها نشانگر آن است كه بين دو گروه هاه همسران مردان داراى اختلالات سايكوز و همسران فاقد اختلال روانى در اين مؤلفه ها تفاوت معنى دارى وجود

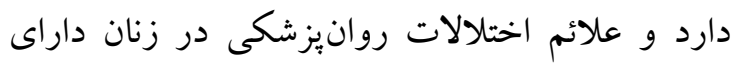
همسر سايكوز بالاتر از خروه ديخر است اما مقدار

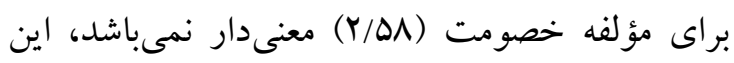

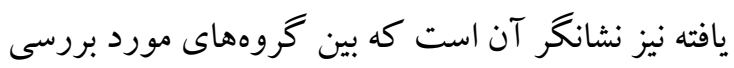
در اين مؤلفه تفاوت معنى دارى وجود ندارد.

جدول ب نتايج آزمون تحليل كواريانس متغير تاب آورى در دو كروه همسر ان مردان داراى اختلالات روانير يشى با كروه شاهد

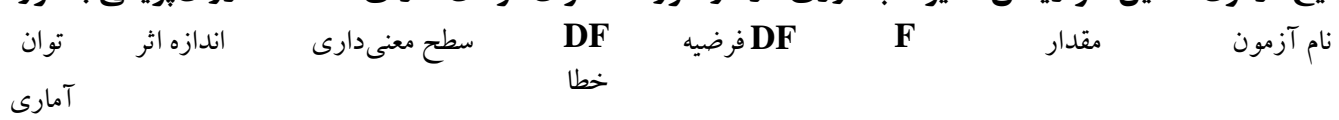

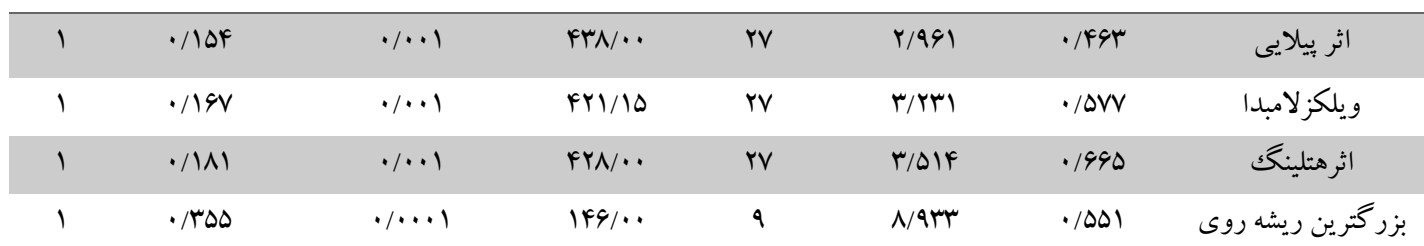

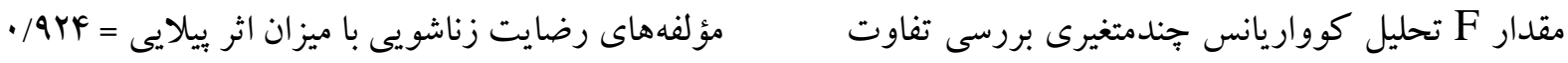

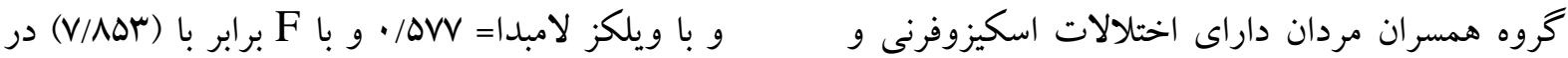

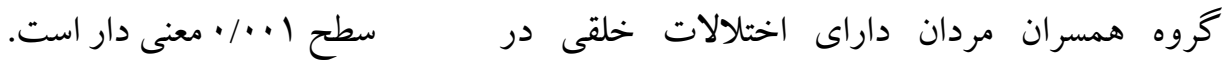

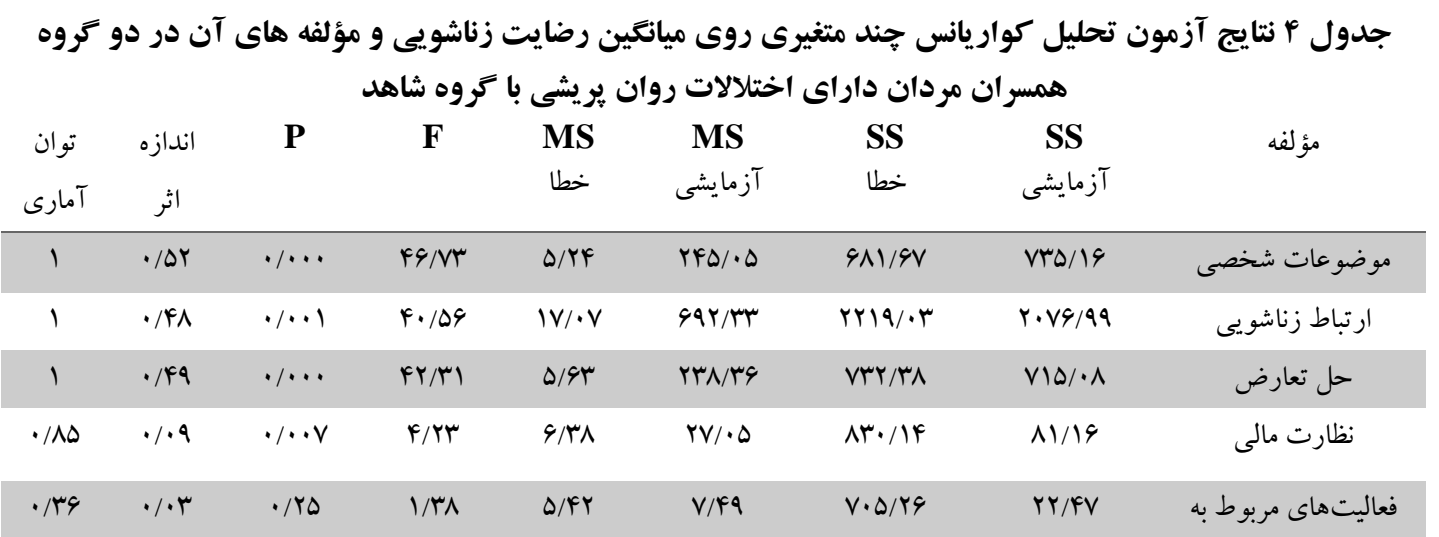




\begin{tabular}{|c|c|c|c|c|c|c|c|c|}
\hline & & & & & & & & اوقات فراغت \\
\hline 1 & $\cdot / 41$ & $\cdot / \cdots$ & $r \cdot / \Lambda$. & $19 / 0 r$ & $4 \cdot 1 / 41$ & rorN/·1 & $M \cdot F / F F$ & روابط جنسى \\
\hline •/V4 & $\cdot / \cdot V$ &.$/ \cdot r$ & $r / F F$ & $N / F 1$ & YN/QV & 1.9r/rr & $\wedge 9 / 91$ & ازدواج و بجههها \\
\hline$\cdot 190$ & .1 .9 & $\cdot / \cdot F$ & $r / V G$ & IN/AY & $01 / 91$ & TFFV/DD & $1 \Delta \Delta / 9 F$ & جهت گيرى عقيدتى \\
\hline$\cdot / 99$ & $\cdot / 19$ & $\cdot / \cdots$ & 1.191 & $199 / \% \Delta$ & IVqV/Ar & $r Y \cdot 1 Q / A r$ & $\Delta r q \mu / F q$ & كل مؤلفهها \\
\hline
\end{tabular}

سلامتى خود را حفظ نمايد (ترزيان و همكاران، .$(Y \cdots V$ نتايج اين يزوهش نشان داد كه در متغير سلامت روان

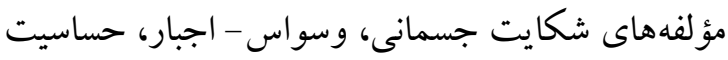
در روابط متقابل، افسردگى، اضطراب، ترس مرضى، افكار يارانوئيدى، روان يريشى وكل مؤلفهها تفاوت معنىدارى بين دو گروه با/ بدون همسر بيمار وجود داشت. آنجه كه قابل توجه است اين كه ميزان نمره در مؤلفهاى نامبرده در زنان داراى همسر اسكيزوفرن بهطور افزايشى بالاتر از زنان داراى همسر سالم بود. علت اين تفاوت مى تواند به دليل گسستخى روانى و علائم قطع ارتباط با واقعيت در مردان بيمار باشد كه نتايج يزوهش حاضر با بزوهش هاى كاگيو يوريزر و

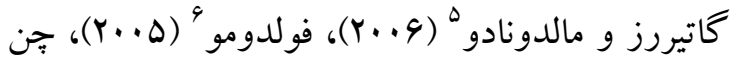
و همكاران (Y.19)، ابراهيمى و همكاران (Y.1Y) (Y.1Y)،

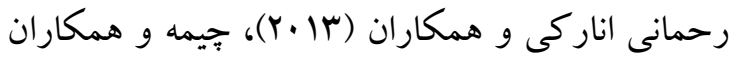

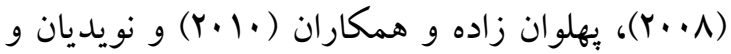

$$
\text { همكاران (r... (Y) همسو است. }
$$

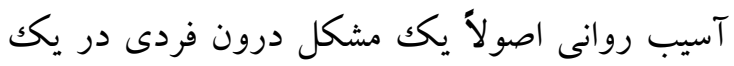
عضو خانواده نيست، بلكه يكك فرايند تعاملى بين اعضاى خانواده است (ملكوتى و همكاران، 9..ب). بروز اشكالاتى نظير وجود بيمارى روانى در يكى از اعضاى خانواده مى تواند اثرات مخرب متعددى را به همراه داشته باشد (هץ! צY) و نشاط و رفاه فردى را از اعضاى خانواده سلب مى كند (رحمانى اناركى و و ولى ونى
با توجه به جدول F مقدار F بر اى مؤلفه هاى موضوعات شخصى (F/NF)، ارتباط زناشويى (F)/D\&)، حل تعارض (اس/F/F)، نظارت مالى ( (F/Y)، روابط جنسى

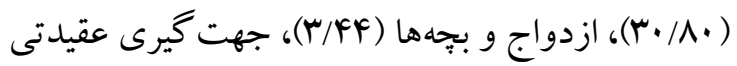

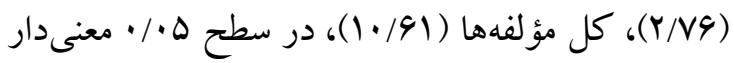
است و اين يافنهها نشانگر آن است كه بين دو گروه همسران مردان داراى اختلالات اسكيزوفرنى و همسران داراى اختلالات خلقى در اين مؤلفهها تفاوت معنى -

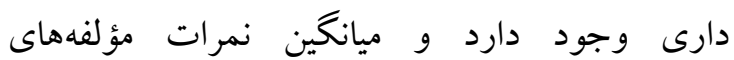
موضوعات شخصيتى، حل تعارض، نظارت مالى، روابط جنسى، جهت گيرى عقيدتى و كل مؤلفهها در

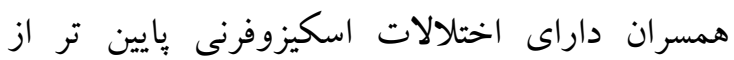
همسران مبتلا به اختلالات خلقى است (در مؤلفههاى

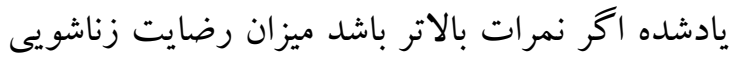

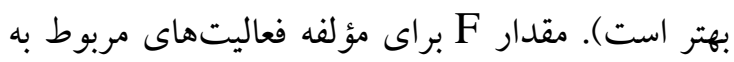

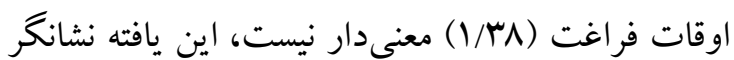
آن است كه بين دو گروه همسران مردان داراى اختلالات اسكيزوفرنى و همسران داراى اختلالات خلقى در اين مؤلفه تفاوت معنىدارى وجود ندارد. زنانى كه داراى همسران مبتلا به اختلالات جدى روانيزشكى دارند به دليل تحمل استرس قابل توجه، اغلب سلامت جسم و روان آنها با خطر مواجه است اما اكر ميزان تاب آور در آنها بالا باشد تا حدود زيادى مىتواند بر استرسهاى مرتبط غلبه كرده و

\footnotetext{
5- Caqueo-Urizar \& Gttierrez-Maldonado 


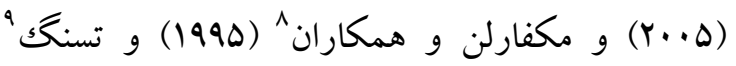

$$
\text { (Y...r) }
$$

\section{نتيجه كيرى}

از إزوهش فوق مى توان نتيجه كرفت كه احساس

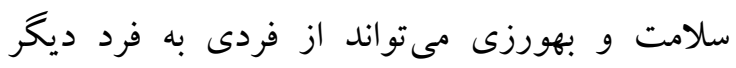
متفاوت باشد. افراد سالم غالباً احساس بيوند با خانواده،

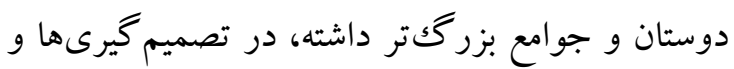
حل مشكلات جامعه مشاركت فعال دارند. سلامت برت روان به ما كمكك مى كند تا با تلاش به اهداف خود در

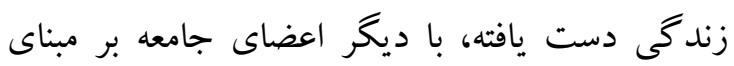

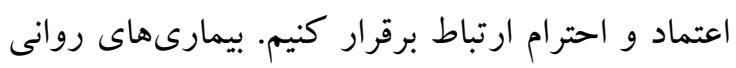

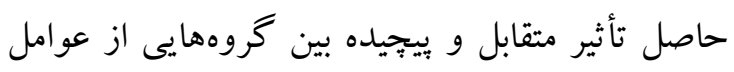

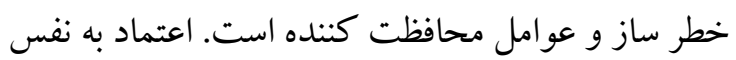

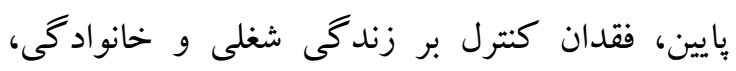
احساس ناامنى و بى ثباتى دائمى هملى عواملى هستند كه به سلامت عمومى و سلامت روان آسيب مىزنئد. عوامل تعيين كننده سلامت در حيطه برابرى و عدالت در دسترسى اعضاى جامعه به منابع بهداشتى و درمانى

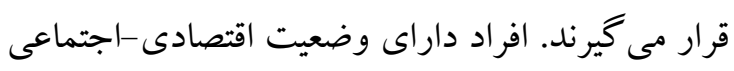
بسيارمتفاوت در كشور ما ايران، سطوح سلامت و

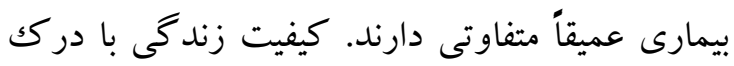
فرد از وضعيت زندگى او از نظر اقتصادى - اجتماعى و دسترسى به حداقل منابع سلامتى ارتباط دارد. رضايت از زندكى كه توسط فرد در حيطههاى جسمى، اجتماعى و روانى گزارش مى شود معرف سطوح كيفيت زندكى افراد جامعه است. براى رسيدن رون به رضايت در زندگى زناشويى عوامل مختلفى مؤثرند؛ تحصيلات و موقعيت اقتصادى و اجتماعى بالاتر به رضايت زناشويى بيشتر مىانجامد كه افراد داراى اين
همكاران، سا •Y). از طرفى در جامعه و فرهنگك ايرانى

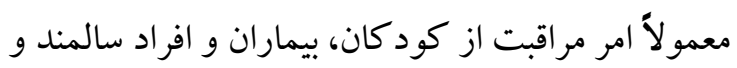
معلول به عهله زنان و دختران خانواده است كه بيكار بوده و به عنوان بخشى از امور خانه دارى و منزل

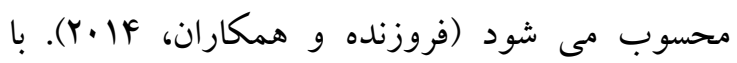
طولانى تر شدن دوره بيمارى و دفعات بسترى مكرر

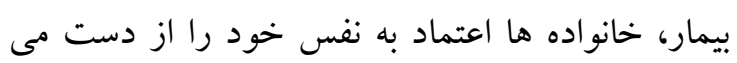
دهند و نخرش آنها نيز به يديده ى بيمارى روانى تغيير

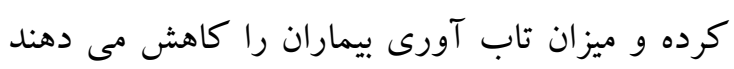
كه نتايج ما با ساير نتايج در ايران همسو است. (نسيمى

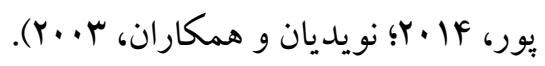
تا كنون فقط سه مطالعه در مورد تاب آورى در اعضاء

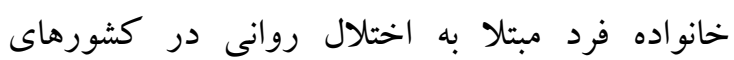
خارجى انجام شده كه هر سه بيش از يكك دهه قبل

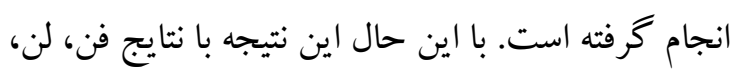

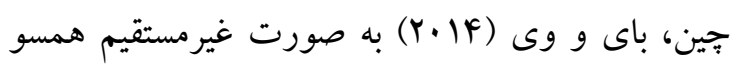
است. بررسى متآناليز نشان داده كه اعضاء خانواده داراى بيماران مبتلا به اختلال روانى در مقياسهاى

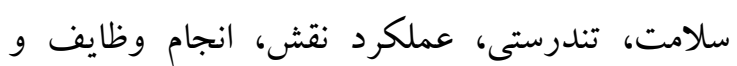
ارزشها و هنجارها شبيه جمعيت عمومى بودند اما بهطور قابل توجهى در مؤلفه هاى حمايت اجتماعى، اعتماد به نفس و معاشرت تفاوت معنى دارى با جمعيت عمومى داشتند و نسبت به جمعيت عمومى كمتر به دنبال حمايت معنوى بودند هر جند آنها با احتمال زياد به دنبال حمايت اجتماعى و تجهيزات فورى خانواده

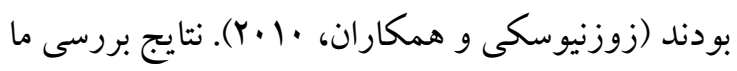
نشان داد كه بين دو گرووه همسر ان، مردان سالم و گرووه همسران مردان داراى اختلالات سايكوز از لحاظ مؤلفه هاى رضايت زناشويى تفاوت معنىدارى وجود دارد. نتايج بثزوهش حاضر با بثوهش رضاى اون ادال لو همكاران 
فرصت لذت بردن از تعامل اجتماعى را از همسران و فرزندانشان سلب كند، اين امر مى تواند سلامت روان، كيفيت زندگى و روابط زناشويى آنان را به درجات متفاوتى تحت تأثير خود قرار دهد. بيشنهاد مى گردد در يثزوهش هاى آينده بر روى متغيرهاى فوق در زنانى كه داراى همسران مبتلا به سايكوز كرونيك هستند يُوهش انجام كيرد تا ميزان آسيب وارده مشخص كردد و از نتايج اين گونه يزوهشهاى براى دريافت تسهيلات براى اين جنين خانوادههايى از سوى مسئولين درخواست كرد.

\section{Refrences}

Awadalla, A.W., Ohaeri, J.U., Salih, A.A. and Tawfiq, A.M., 2005. Subjective quality of life of family caregivers of community living Sudanese psychiatric patients. Social psychiatry and psychiatric epidemiology, 40(9), pp.755-763.

Awadalla, A.W., Ohaeri, J.U., Salih, A.A. and Tawfiq, A.M., 2005. Subjective quality of life of family caregivers of community living Sudanese psychiatric patients. Social psychiatry and psychiatric epidemiology, 40(9), pp.755-763.

Babakhani, N., Asadi Niazi, S.H., Alizadehzakaria, R., Bakhtiari Araksi, H., 2016. The Relationship of Identity Styles with Marital Satisfaction in Married Couples in Tehran. Fundamentals of Mental Health, 18, pp. 471-477.

Bland, R. and Darlington, Y., 2002. The nature and sources of hope: Perspectives of family caregivers of people with serious mental illness. Perspectives in Psychiatric Care, 38(2), pp.61-68.

Caqueo-Urízar, A. and Gutiérrez-Maldonado, J., 2006. Burden of care in families of patients with schizophrenia. Quality of Life Research, 15(4),pp.719-724.

Caqueo-Urízar, A. and Gutiérrez-Maldonado, J., 2006. Burden of care in families of patients with schizophrenia. Quality of Life Research, 15(4),pp.719-724.

$$
\begin{aligned}
& \text { موقعيتها احتمالاً داراى مهارتهاى حل مشكل بهترى } \\
& \text { هستند و استرسهاى مزمن كمترى را دركك و حس } \\
& \text { مى كنند. يزوهش ها نشان داده كه روابط دو نفره زن و } \\
& \text { شوهر در بين ساير ابعاد ساز كارى زناشويى نقش } \\
& \text { محورى دارد. اين روابط شامل دركك و فهم صميميت، } \\
& \text { همدلى، مراودات كلامى و غير كلامى در بين زوجين } \\
& \text { است. وجود يكك همسر بيمار مبتلا به اختلال سايكوز } \\
& \text { كه ارتباط وى با جهان واقعيت بير امونش قطع شده مى } \\
& \text { تواند جالش هاى زيادى را براى زنانى كه سريرست } \\
& \text { خود را به كونه ای از دست داده اند ايجاد كند. اين } \\
& \text { زنان علاوه بر تحمل هزينه درمان؛ مشكلات روحى } \\
& \text { زيادى را نيز تجربه كنند. رفتارهاى مخرب اين بيماران }
\end{aligned}
$$

Chadda, R.K., 2014. Caring for the family caregivers of persons with mental illness. Indian journal of psychiatry, 56(3), p.221.

Chen, X., Mao, Y., Kong, L., Li, G., Xin, M., Lou, F. and Li, P., 2016. Resilience moderates the association between stigma and psychological distress among family caregivers of patients with schizophrenia. Personality and Individual Differences, 96, pp.78-82.

Chimeh, N., Malakooti, K., Panaghi, L., Ahmad Abadi, Z, Nojoomi, M., Tonkaboni, A., 2008. Factors Affecting Bumout and Mental Health of Carers of Schizophrenic Patients. Quarterly Joumal of Family Studies, 4( 15), pp. 292-277.

Connor, K.M. and Davidson, J.R., 2003. Development of a new resilience scale: The Connor-Davidson resilience scale (CD-RISC). Depression and anxiety, 18(2), pp.76-82.

Cowling, V., Luk, E.S., Mileshkin, C. and Birleson, P., 2004. Children of adults with severe mental illness: Mental health, help seeking and service use. Psychiatric Bulletin, 28(2), pp.43-46.

Ebrahimi, H., Seyedfatemi, N., Namdar Areshtanab, H., Ranjbar, F., Thomicroft, G., Whitehead, B. and Rahmani, F., 2018. Barriers to Family Caregivers' Coping With Patients 
With Severe Mental Illness in Iran. Qualitative health research, 28(6), pp.9871001.

Ettinger, U., Meyhöfer, I., Steffens, M., Wagner, M. and Koutsouleris, N., 2014. Genetics, cognition, and neurobiology of schizotypal personality: a review of the overlap with schizophrenia. Frontiers in psychiatry, 5, p.18.

Fallahi, M., Maddah Sadat, M., Shamloo, S., 2005. Designing a Multidimensional Psychological Rehabilitation Nursing Model in the Care of Schizophrenic Patients. Journal of Shahid Sadoughi University of Medical Sciences and Health Services, (3), pp. 46-39.

Fan, Y.C., Chen, M.B., Lin, K.C., Bai, Y.M. and Wei, SJ., 2014. The resilience and health status of primary caregivers of schizophrenia patients. Hu LiZaZhi, 61(6),p.29.

Foldemo, A., Gullberg, M., Bogren, L., 2005, Quality of life and burden in parents of outpatients with schizophrenia. Social Psychiatry and Psychiatric Epidemiology, 40(2), PP. 133-8.

Fonuzandeh, N., Delaram, M., Noorian, K. and Deris, F., 2014. Comparision of family function in the families of psychiatric patients with difference diagnosis. J Res Behave Sci, 11(15).

Guơmundsson, Ó.Ó. and Tómasson, K., 2002. Quality of life and mental health of parents of children with mental health problems. Nordic joumal of psychiatry, 56(6), pp.413417.

Haresabadi, M., Bibak, B., Hosein, Z.E., Bayati, M., Arki, M., Akbari, H., 2012. Assessing burden of family caregivers of patients with schizophrenia admitted in Imam Reza Hospital-Bojnurd 2010. Joumal of North Khorasan University of Medical Sciences, 4(2): 165-171.

Herbert, H.S., Manjula, M. and Philip, M., 2013. Growing up with a parent having schizophrenia: Experiences and resilience in the offsprings. Indian joumal of psychological medicine, 35(2), p.148.

Imran, H. and Dilawer, R., 2016. MENTAL HEALTH ISSUES AMONG SPOUSES OF PATIENTS WITH PSYCHIATRIC
DISORDERS. Pakistan Journal of Clinical Psychology, 15(2).

Kate, N., Grover, S., Kulhara, P. and Nehra, R., 2013. Relationship of caregiver burden with coping strategies, social support, psychological morbidity, and quality of life in the caregivers of schizophrenia. Asian joumal of psychiatry, 6(5), pp.380-388.

Koujalgi, S.R. and Patil, S.R., 2013. Family burden in patient with schizophrenia and depressive disorder. a comparative study. Indian joumal of psychological medicine, 35(3), p.251.

Li, J., Lambert, C.E. and Lambert, V.A., 2007. Predictors of family caregivers' burden and quality of life when providing care for a family member with schizophrenia in the People's Republic of China. Nursing \& health sciences, 9(3), pp.192-198.

Malakooti, K., Chimeh, N., Panaghi, N., Ahmadabadi, Z., Nojoomi, M., 2009. The Effectiness of two Case Management Methods on Mental Health, Knowledge, and Burden of Schizophemics, Family Member. Journal of Family Research, 5(1), pp.29-42.

McFarlane, W.R., Link, B., Dushay, R., Marchal, J. and Crilly, J., 1995. Psychoeducational multiple family groups: Four-year relapse outcome in schizophrenia. Family process, 34(2), pp.127-144.

Modabernia, M.J., Shojaie Tehranie, H., Falahi, M. and Faghimpour, M., 2010. Normalizing SCL-90-R inventory in Guilan high-school students. Joumal of Guilan University of Medical Sciences, 19(75), pp.58-65.

Mohammadi, M., 2004. Factors Affecting Resilience in Persons at Risk of Substance Abuse. Doctoral thesis. University of Social Welfare and Rehabilitation Sciences, Tehran.

Mulud, Z.A. and McCarthy, G., 2017. Caregiver burden among caregivers of individuals with severe mental illness: testing the moderation and mediation models of resilience. Archives of psychiatric nursing, 31(1), pp.24-30.

Nasimi poor, M., 2014. Comparison of quality of life and mental health of spouses of patients with schizophrenia, bipolar disorder, major depression and normal people. New 
Psychological Research (Psychology of Tabriz University), 34 (9), pp. 173-193.

Navidian, A., Salar, A., Kermansaravi, F., 2003. The Surveying the Psychological Pressure of Family Carers of Mental Patients Referring to Zahedan Hospital and Comprehensive Psychiatric Center. Teb va Tazkiyeh, 13(1), pp. 0-19.

Oza, H., Parikh, M.N. and Vankar, G.K., 2017. Comparison of caregiver burden in schizophrenia and obsessive-compulsive disorder. Archives of Psychiatry and Psychotherapy, 2, pp.32-41.

Pahlavan, S., Navidian, A., Yazdani, M., 2010. The effect of family psychosocial education on the amount of depression, anxiety and stress among family carers of psychiatric patients. Journal of Kermanshah University of Medical Sciences, (3), pp.236-228.

Prior, J., Abraham, R., Nicholas, H., Chan, T., Vanvlymen, J., Lovestone, S. and Boothby, H., 2016. Are premorbid abnormal personality traits associated with behavioural and psychological symptoms in dementia?. International journal of geriatric psychiatry, 31(9), pp.1050-1055.

Rahmani Anaraki, H., Mahmoodi, G. R., Rouhi, G., Asayesh, H., Nasiri, H., Rakhshani, H., 2013. General Health Status of Neurologic Patients' Caregivers and The Related Factors. Jgbfnm, 9 (2) , pp.49-55.

Robinson, C.A., 2017. Families living well with chronic illness: The healing process of moving on. Qualitative health research, 27(4), pp.447-461.

Sadock, BJ., Sadock, V.A., Ruiz, P., 2014. Kaplan and Sadock's Synopsis of Psychiatry: Behavioral Sciences/Clinical Psychiatry. 11 thed. New York: Wolters Kluwer.

Sales, E., 2003. Family burden and quality of life. Quality of life research, 12(1),pp.33-41.

Soltaninejad, A., von Kardorff, E., Kamali, M. and Shahrbabaki, M.E., 2017. Development and Validation of a Questionnaire to Measure
Quality of Life in Caregivers of Patients with Schizophrenia and Affective Disorders (SAC-QoL). Iranian Joumal of Psychiatry and Behavioral Sciences, 11(2).

Stjemswärd, S. and Östman, M., 2008. Whose life am I living? Relatives living in the shadow of depression. Intemational Joumal of Social Psychiatry, 54(4), pp.358-369.

Techinsky, U., 2000. Living with schizophrenia: the family experience. Issues Ment Health Nurs, 21(4), pp.387-396.

Terzian, A.C.C., Andreoli, S.B., De Oliveira, L.M., de Jesus Mari, J. and McGrath, J., 2007. A cross-sectional study to investigate current social adjustment of offspring of patients with schizophrenia. European archives of psychiatry and clinical neuroscience, 257(4), pp.230-236.

Tsang, H.W., Tam, P.K., Chan, F. and Chang, W.M., 2003. Sources of burdens on families of individuals with mental illness. Intemational joumal of rehabilitation research, 26(2), pp.123-130.

Ungar, M., Brown, M., Liebenberg, L., Othman, R., Kwong, W.M., Armstrong, M. and Gilgun, J., 2008. Unique pathways to resilience across cultures. Youth Studies Australia, 27(2), pp.63-64.

Vella, S.L. and Pai, N., 2013. The measurement of burden of care in serious mental illness: a qualitative review. Australian \& New Zealand Joumal of Psychiatry, 47(3), pp.222-234.

Wang, S.H., Rong, J.R., Chen, C.C., Wei, S.J. and Liu, K.C., 2007. A study of stress, leamed resourcefulness and caregiver burden among primary caregivers of schizophrenic adolescents. Hu li za zhi The joumal of nursing, 54(5),pp.37-47.

Zauszniewski, J.A., Bekhet, A.K. and Suresky, M.J., 2010. Resilience in family members of persons with serious mental illness. Nursing Clinics, 45(4), pp.613-626. 